\title{
Leisure travelling and its link to an active and healthy ageing
}

\begin{abstract}
The silver market is a driving force in the tourism and hospitality industry and one of its fastest growing and most evolving segments. The increased importance of the senior market is not only the result of demographic changes and a worldwide trend towards an ageing population ${ }^{1}$ but is also caused by behavioral shifts on the part of increasingly active older adults. ${ }^{2}$ According to Leeson, ${ }^{3}$ population structure and not just size is seen as critical for the impact our demographies around the world have on our environment. ${ }^{4}$

In this context, it is of paramount interest for the tourism industry to understand the travel behaviour of the elderly in order to effectively adjust existing tourism products to their needs. ${ }^{5}$ But beyond the lucrative benefits for tourism organizations, a step further towards a deeper comprehension on the benefits from leisure travelling linked to a active ageing and wellbeing is crucial. There is a gap on literature and academic research on the importance of travelling and its role on active and healthy ageing. A general overview on the importance of a better understanding on this link will be reported.
\end{abstract}

Volume I Issue 4 - 2017

\section{Balderas Cejudo, Maria Adela, Leeson G}

Oxford Institute of Population Ageing, University of Oxford, UK

Correspondence: Maria Adela, Oxford Institute of Population Ageing, University of Oxford, UK,

Email maria.balderascejudo@ageing.ox.ac.uk

Received: May 27, 2017 | Published: June 26, 2017

\section{Introduction}

In demographic terms, markets are shifting towards an ageing population, particularly in developed countries, where the main tourist markets are located. This trend has resulted in a large segment that is quite attractive to providers of tourist services known as the "senior" or "grey" segment. ${ }^{6}$ Most researchers are in agreement that older adults will prefer to take leisure trips. Indeed Capella and $\mathrm{Greco}^{7}$ found that $50 \%$ of those aged 65 years and over took a vacation at least once a year, and Blazey ${ }^{8}$ pointed out that the number one thing that people wanted to do when they retired was to travel. ${ }^{9}$ The emergence of new tourist profiles is an ongoing process, resulting from the dynamics of changes in society. ${ }^{10}$

According to UN (2015), globally, in 2015 there were 901 million people aged 60 years or over. This was an increase of $48 \%$ over the number of 607 million older persons who were living globally in 2000. By 2030 the number of people in the world aged 60 years or over is projected to grow by $56 \%$, to 1.4 billion, and by 2050 the global population of older persons is projected to more than double its size to reach nearly 2.1 billion. ${ }^{11}$ The world's population is ageing with virtually every country in the world experiencing growth in the number and proportion of older people in the population. Never before has humanity seen such a development: a shrinking of younger populations in almost all developed countries and at the same time a considerable ageing of their residents. ${ }^{12}$ The age composition of the worlds population is altering as the median age rises and that a proportionate shift from younger to older people continues. ${ }^{13}$

Population ageing is poised to become one of the most significant social transformations of the 21 st century, with implications for nearly all sectors of society. These sectors include labour and financial markets, housing, transportation and social protection, as well as changes in family structures and inter-generational ties (UN, 2015), and the tourism industry will not be an exception. The demand for leisure and tourism activities has grown steadily in our society, and these are now regarded as important aspects of life for enhancing psychological and physical well-being, ${ }^{14}$ and to assist in the achievement of a successful retirement. ${ }^{15}$
On average, seniors are healthier, wealthier, and better educated; they have richer life experiences and are more experienced travellers. They are also likely to be more active and independent and have more interests compared to older people in the past. It has also been proposed that they place tourism high in their priorities ${ }^{16,17}$ and that they have a relatively large share of discretionary money which they are willing to spend on travel..$^{18}$ Greater discretionary income, the changing age patterns of consumers and more free time are seen as essential factors for an increase in the travel demand of this segment. As more and more people move into an advanced stage of their life, more people of this group will still want to travel. ${ }^{19}$

An important number of studies and researchers have confirmed that the senior market segment will be one of the largest in history and have a great impact to the tourism industry because of its size and the increasing amount of disposable money that seniors will spend on consumer industries. Nevertheless, until recently and despite the important academic interest in the older consumer segments mainly in the U.S.A., older consumers had been largely neglected or ignored by the marketing community, which mostly concentrated on younger markets. ${ }^{20-22}$ While research has been conducted on tourism planning, development, and marketing, various aspects of seniors' travel experiences still require investigation ${ }^{23}$ as the senior tourism market segment remains a relatively unexplored research theme..$^{24}$

Furthermore and regarding leisure tourism linked to active ageing and wellbeing, tourism or leisure travel has not received sufficient attention in aging research. ${ }^{25,26}$ To this day, one of the biggest challenges that industries face is the lack of information or knowledge as to who their older customers are, and what their customers need. ${ }^{27}$ The aim of the current research is a deeper comprehension not only of the senior tourism segment from a market segment perspective but also the relevance of leisure travelling on an active ageing and well being.

\section{Summary of research findings}

There is a need to explore what seniors want and need and the role that active ageing and health can have on tourism consumption 
in the segment of seniors. The active ageing approach is based on the recognition of the human rights of older people and the United Nations Principles of independence, participation, dignity, care and self-fulfilment. It shifts strategic planning away from a "needs-based" approach (which assumes that older people are passive targets) to a "rights- based" approach that recognizes the rights of people to equality of opportunity and treatment in all aspects of life as they grow older. It supports their responsibility to exercise their participation in the political process and other aspects of community life. WHO (2003) standpoint is that advanced age is not necessarily a contraindication for travel if the general health status is good. Indeed, from a consumer perspective, holidays can provide many benefits to somebody with ill-health. Tourism is considered, in the World Tourism Organization WTO's Global Code of Ethics for Responsible Tourism, ${ }^{28}$ as an important means for achieving personal and collective fulfillment as well as for having access to and enjoying the 'planet's resources' (Article 2, Number 1; Article 7, Number 1).

According to Ferrer et al. ${ }^{25}$ it is generally accepted that holiday tourism is a positive and healthy pursuit to follow in leisure time, ${ }^{29}$ providing many benefits to mental and psychical health. Across a range of contexts, the links between holiday taking and quality of life, health, stress reduction, active life and healthy lifestyle have been demonstrated. Travel has been positively correlated with physical health outcomes -specifically, risk of cardiovascular heart disease amongst middle-aged men. ${ }^{30}$ People often feel happier, healthier and more relaxed after a pleasure trip, although these effects are limited in strength and duration after the holiday. ${ }^{31}$

Following Nella et al. $^{32}$ the continuous monitoring of market trends is one of the most important roles that marketing, scientists and practitioners should fulfill. As tourism is significantly affected by major demographic, cultural and economic trends, this responsibility becomes crucial not only for destination marketers and other tourism marketers but also for all stakeholders and practitioners linked to new venues towards wellbeing and healthy ageing.

\section{Practical implications and further research}

To cater to the diversity of needs of the seniors' market, a more comprehensive understanding of travel behavior is necessary in order for tourism products and services to be tailored to match preferences for travel and gain market advantages. ${ }^{33-36}$ Besides, according to our view, more emphasis should be put to gain understanding on the link between health and leisure travelling from the inner voices of senior travellers. In order to identify consumption patterns among senior tourists and how they affect their feelings, experiences, needs, preferences, ideas and interpretations, a qualitative research approach should be adopted. Quite apart from the quantitative characteristics of senior travelers, additional qualitative parameters should be carefully considered. The dominance of the quantitative approach is evident in previous research studies on senior tourism. However following Patterson, ${ }^{1}$ researchers should further develop and apply qualitative methods that will enable them, "to gain a better and more in-depth recollection and understanding of the actual trip experience" (2006: 40). He argued that relatively little research has sought to understand the meaning of tourism and leisure for older people, and that it is not possible to study older people's behaviour through 'snapshot' research, which isolates a single moment in time. Sedgley et al. ${ }^{26}$ also called for the application of more qualitative methods to examine the full breath of the subject but also for more cross-disciplinary enquiries - particularly in gerontology- to provide meaningful insight into lives of this population. ${ }^{37}$

Understanding what type of tourism that seniors want to do in the future, their future motivations and behaviour, matching their changing needs and accounting for these changes in a proactive way may: (1) provide lucrative benefits and exciting opportunities for research; (2) give relevant inputs for managing active and healthy ageing issues and (3) develop knowledge and expertise on social tourism programmes for seniors with less opportunities to participate in tourism and which may improve their quality of life in many ways. ${ }^{38}$ Furthermore, according to Hung et al..$^{39-41}$ findings generated by this approach may help create innovative ways to address some of the gaps identified in the literature. Further studies should also be undertaken this kind of research and deepen into social tourism programmes for seniors "which is a field of research that has been widely neglected" Eusebio et al. ${ }^{38}$

\section{Acknowledgments}

None.

\section{Conflict of interest}

Authors declare there is no conflict of interest in publishing the article.

\section{References}

1. Patterson IR. Growing older: Tourism and leisure behaviour of older adults. Cabi, Australia; 2006.

2. Lohmann M, Aderhold P. Die RA-Trendstudie - Entwicklung der touristischen Nachfrage der Deutschen (Holiday travel trends 2020 - the RA trend survey - development of tourist demand among Germans). FUR, Urlaubsreisetrends 2020 Kiel, Germany; 2009.

3. Leeson GW. Environment, Health and Ageing. In Environmental Gerontology in Europe and Latin America. International Perspectives on Aging. 2016;13:93-104

4. Royal Society. People and the planet. The Royal Society Science Policy Centre. London; 2012.

5. Huber D, Milne S, Hyde KF. Biographical Research Methods and Their Use in the Study of Senior Tourism. International Journal of Tourism Research. 2017;19(1):27-37.

6. Santos MC, Veiga C, Águas P. Tourism services: facing the challenge of new tourist profiles. Worldwide Hospitality and Tourism Themes. 2016.

7. Capella LM, Greco AJ. Information sources of elderly for vacation decisions. Annals of Tourism Research. 1986;14(1):148-151.

8. Blazey MA. Travel and Retirement Status. Annals of Tourism Research. 1992;19(4):771-783.

9. Dann S. Branded generations: baby boomers moving into the seniors market. Journal of Product \& Brand Management. 2007;16(6):429-431.

10. Kotler P, Keller K. Lane. 2nd ed. Marketing management. USA; 2012.

11. Nations U. Transforming our world: The 2030 agenda for sustainable development. Department of Economic and Social Affairs, USA; 2015.

12. Meiners NH, Seeberger B. Marketing to senior citizens: Challenges and opportunities. The Journal of Social, Political and Economic Studies. 2010;35(3):293.

13. Harper S. Economic and social implications of aging societies. Science. 2014;346(6209):587-591. 
14. Janke M, Davey A, Kleiber D. Modeling change in older adults' leisure activities. Leisure Sciences. 2006;28(3):285-303.

15. Silverstein M, Parker MG. Leisure activities and quality of life among the oldest old in Sweden. Research on Aging. 2002;24(5):528-547.

16. Statts S, L Pierfelice. Travel: A Long-Range Goal of Retired Women. The Journal of Psychology. 2003;137(5):483-494.

17. Serre LD, Chevalier C. Marketing travel services to senior consumers. Journal of Consumer Marketing. 2012;29(4):262-270.

18. Patterson I. Information sources used by older adults for decision making about tourist and travel destinations. International Journal of Consumer Studies. 2007;31(5):528-533.

19. Möller C, Weiermair K, Wintersberger E. The changing travel behaviour of Austria's ageing population and its impact on tourism. Tourism Review. 2007;62(3/4):15-20.

20. Swayne LE, Greco AJ. The portrayal of older Americans in television commercials. Journal of Advertising. 1987;16(1):47-54.

21. Carrigan M, Szmigin I. In pursuit of youth: what's wrong with the older market? Marketing Intelligence \& Planning. 1999;17(5):222-231.

22. Szmigin I, Carrigan M. Learning to love the older consumer. Journal of Consumer Behaviour. 2001;1(1):22-34.

23. Lu J, Hung K, Wang L, et al. Do perceptions of time affect outboundtravel motivations and intention? An investigation among Chinese seniors. Tourism Management. 2016;53:1-12.

24. Bornhorst T, Ritchie JB, Sheehan L. Determinants of tourism success for DMOs \& destinations: An empirical examination of stakeholders' perspectives. Tourism management. 2010;31(5):572-589.

25. Ferrer JG, Sanz MF, Ferrandis ED, et al. Social tourism and healthy ageing. International Journal of Tourism Research. 2015;18(4):297-307.

26. Sedgley D, Pritchard A, Morgan N. Tourism and aging: A transformative research agenda. Annals of Tourism Research. 2011;38(2):422-436.

27. Jang S, Ham S. A double, hurdle analysis of travel expenditure: Baby boomer seniors versus older seniors. Tourism Management 2009;30(3):372-380
28. UNWTO. Tourism Highlights. World Tourism Organization, Spain; 2011.

29. Hobson JSP, Dietrich UC. Tourism, Health and Quality of Life. Journal of Travel \& Tourism Marketing. 1995;3(4):21-38.

30. Gump BB, Karen AM. Are vacations good for your health? The 9-year mortality experience after the multiple risk factor intervention trial. Psychosom Med. 2000;62(5):608-612.

31. Bloom DJ, Geurts SAE, Sonnentag S, et al. How Does a Vacation from Work Affect Employee Health and Well-Being? Psychol Health. 2011;26(12):1606-1622.

32. Nella A, Christou E. Extending tourism marketing: Implications for targeting the senior tourists' segment. Munich Personal RePEc Archive. 2016;2(1):36-42.

33. Horneman L, Carter RW, Wei S, et al. Profiling the senior traveler: an Australian perspective. Journal of Travel Research. 2002;41(1):23-37.

34. State M, Nedelea A. The Demographic Ageing and Consumer Market. Journal of the Faculty of Economics. Romania; 2008.

35. Balderas CA, Rivera HO, Patterson I. The Strategic Impact of Country of Origin on Senior Tourism Demand: the Need to Balance Global and Local Strategies. Journal of Population Ageing. 2016;9(4):345-373.

36. Patterson I, Sie L, Balderas CA, et al. Changing trends in the baby boomer travel market: importance of memorable experiences. Journal of Hospitality Marketing \& Management. 2017;26(4):347-360.

37. Kazeminia A, Del Chiappa G, Jafari J. Seniors' travel constraints and their coping strategies. Journal of Travel Research. 2015;54(1):80-93.

38. Eusébio C, Carneiro MJ, Kastenholz E, et al. Social tourism programmes for the senior market: a benefit segmentation analysis. Journal of Tourism and Cultural Change. 2017;15(1):59-79.

39. Huang L, Tsai HT. The study of senior traveler behavior in Taiwan. Tourism Management. 2003;24(5):561-574.

40. Gu D, Zhu H, Brown T, et al. Tourism experiences and self-rated health among older adults in China. J Aging health. 2016;28(4):675-703.

41. http://mkt.unwto.org/sites/all/files/docpdf/unwtohighlights11enhr.pdf 